УДК 633.15

(C) 2013

Харченко Ю. В., кандидат сільськогосподарських наук, Харченко Л. Я., науковий співробітник

Устимівська дослідна станція рослинництва Інституту рослинництва ім. В. Я. Юр'єва НААНУ

\title{
ВИХІДНИЙ МАТЕРІАЛ ДЛЯ СЕЛЕКЦІЇ КУКУРУДЗИ
}

\author{
Рецензент - кандидат сільськогосподарських наук О. В. Тригуб
}

\begin{abstract}
На Устимівській дослідній станиії рослинництва протягом 2008-2010 рр. проведено вивчення 110 зразків кукурудзи. За результатами вивчення господарсько-біологічних властивостей виділено низку форм, котрі є джерелами господарськи иінних ознак. Проведено розподіл зразків по групах стиглості. Виділено лінії та сорти з підвищеним вмістом білку та крохмалю в зерні кукурудзи. На природному фоні виділено зразки, стійкі до шкідників та хвороб. Результати комплексного вивчення колекиії кукурудзи свідчать про необхідність залучення нових форм, популяцій, ліній, місиевих зразків

народної селекиії з різних країн світу і регіонів

Украйни з метою подальшого їх випробування та включення в селекиійний процес.
\end{abstract}

Ключові слова: кукурудза, селекиійні сорти, самозапилені лінії, місцеві сорти, елементи, продуктивність, господарськи иінні властивості, білок.

Постановка проблеми. Кукурудза стала найважливішою зерновою і кормовою культурою сучасного землеробства.

За врожайністю вона займає перше місце в світі, значно випереджаючи інші зернові культури.

Поширення кукурудзи у світовому землеробстві пояснюється іiї біологічними особливостями, пристосованістю рослин до різних умов вирощування, а також високою урожайністю в зв'язку 3 використанням явища гетерозису.

Для створення сучасних гібридів потрібно мати різноманітний вихідний матеріал - самозапилені лінії, що мають властивості передавати гібридам цінні ознаки $[4,5,14,17]$.

Тобто, селекціонерам потрібні вдосконалені самозапилені лінії, в яких разом із господарськими ознаками були б підвищені адаптаційні властивості до екологічних умов зони.

Нові лінії можна одержати 3 придатних місцевих і селекційних сортів, популяцій, ранньостиглих і середньоранніх гібридів світової та вітчизняної селекції, синтетичних популяцій.

Про підвищену цікавість селекціонерів до місцевих сортів, як джерел цінних генів, свідчить низка повідомлень $[6,7,17,18]$.
Аналіз основних досліджень і публікацій, у яких започатковано розв'язання проблеми. Створюючи гібриди, селекціонер повинен чітко уявляти, для якої екологічної зони вони будуть призначатися. Відповідно до зони повинен підбиратися вихідний матеріал. Козубенко Л. В., Гур'єва I. А., Кузьмишина Н. В. [6, 12] наголошують, що значну увагу слід приділяти реакції кукурудзи на стресові умови середовища. Залежно від рівня стресу відбувається ослаблення прояву окремих морфологічних ознак, а деякі 3 них зовсім не проявляються. Відмічено, що окремі зразки по-різному реагують на стресові умови: одні з них порівняно легко переносять несприятливі умови, на інші стрес згубно впливає на окремих фазах розвитку. Відомо, що понижені температури в період з'явлення сходів впливають на процеси первинного росту і листоутворення. У зразків, що характеризуються холодостійкістю, сходи зазвичай з'являються раніше за пониженої температури грунту i повітря, рослини зберігають зелений колір і не знижують інтенсивності росту. У них часто відмічається генетичний захист на дію понижених температур - опушення листових пластинок, восковий наліт, утворення захисного антоціанового забарвлення листків та стебла. Визначаючи рівень стійкості вихідного матеріалу до понижених весняних температур, виділяють холодостійкі форми та використовують як безпосередньо в селекційному процесі, так і для створення нових сучасних ліній $[2,14$, 16]. Відомо, що більшість регіонів України підпадають під дію атмосферної і грунтової посухи, яка негативно діє як на ріст і розвиток рослин кукурудзи, так і на формування врожаю зерна. Періодичні посухи супроводжуються високими температурами $\left(+39 \ldots+40{ }^{\circ} \mathrm{C}\right)$, що є причиною череззерниці та неозерненості початків і значного зниження врожайності [1]. Козубенко В. О. [9] вважав, що зменшити втрати продуктивності зерна у ліній і гібридів кукурудзи під дією посухи можна завдяки використанню багатокачанних форм, у яких в стресових умовах формується хоча б один повноцінний початок, у той час як у 
однокачанних форм часто виникає безплідність рослин. Значна увага у вивченні ліній кукурудзи як вихідного матеріалу приділяється стабільності продуктивності та їі елементів [3]. Продуктивність зерна 3 однієї рослини визначається кількістю зерен та їх масою. Кількість зерен на початку залежить від кількості рядів і зерен у ряду. Більш стабільною ознакою $є$ кількість рядів. Опосередковано кількість зерен у ряді залежить від довжини початку $[8,10,12]$. Залежно від стресових умов може зменшуватись одна 3 перерахованих ознак. Наприклад, у разі високої температури під час запилення гине пилок, що спричинює високий відсоток череззерниці. За сприятливих умов температури та вологи зерно інтенсивно накопичує продукт фотосинтезу i, таким чином, компенсується рівень продуктивності за рахунок підвищеної маси 1000 зерен $[4,6]$. Тому залучаючи вихідний матеріал потрібно зважати на стресові погодні умови зони, де ведеться селекція, i добирати його за комплексом ознак: придатністю до механізованого вирощування, стійкістю до хвороб та шкідників, біохімічним складом зерна. Ефективність гетерозисної селекції кукурудзи визначається наявністю різноманітних самозапилених ліній, цінних за низкою господарських та біологічних ознак. Сучасна гетерозисна селекція кукурудзи для вирішення основного завдання - значного підвищення врожайності гібридів потребує залучення в селекційні програми широкого різноманіття вихідного матеріалу та розробки нових підходів до його використання $[3,6,7]$.

Мета досліджень полягає у визначенні селекційної цінності колекційного матеріалу кукурудзи за основними господарськи цінними ознаками та добір найбільш придатних ліній і сортів для використання в селекційних програмах із метою створення високоврожайних, стійких до стресових умов середовища захворювань та пристосованих до механізованого збирання гібридів кукурудзи, а також формування ознакових колекцій самозапилених ліній та сортів для подальшого залучення в селекційний процес.

Відповідно до поставленої мети вирішувалася низка завдань:

- провести розподіл колекційного матеріалу за тривалістю вегетаційного періоду, морфологічними ознаками, ознаками продуктивності та іiі складовими (кількість початків на рослині, кількість рядів зерен, кількість зерен у ряду, вага 1000 зерен);
- виділити зразки - джерела та донори господарськи цінних ознак для різних напрямів селекції кукурудзи;

- сформувати ознакові колекції самозапилених ліній та сортів для подальшого залучення до селекційного процессу;

- за результатами вивчення зареєструвати в Національному центрі генетичних ресурсів рослин України цінні зразки кукурудзи.

Умови та методика проведення досліджень. У 2008-2010 рр. на Устимівській дослідній станції рослинництва проведено комплексне вивчення 110 зразків кукурудзи. Для проведення дослідження використано матеріал із колекції Устимівської дослідної станції. 3 них самозапилених ліній -47 , селекційних сортів - 10 , місцевих сортів - 46, гібридних популяцій -7. Зразки походять з України (70), Росії (12), Молдови (8), Угорщини (6), Австрії (3), Словаччини (1), Болгарії (1), Німеччини (1), Австрії (1), Албанії (2), Великобританії (3), США (1), Казахстану (1) й відносяться до кременистого, зубоподібного та напівзубоподібного підвидів.

Дослідження проводили в польових умовах Устимівської дослідної станції рослинництва, в центральній частині Лівобережної України, на межі між Лісостеповою та Степовою зонами.

Грунт - середньосуглинистий, малогумусний, розпилений чорнозем. Оцінку зразків проводили згідно 3 «Методичними рекомендаціями польового та лабораторного вивчення генетичних ресурсів рослин України» [13] та «Класифікатором-довідником виду Zea mays L.» [11].

Зразки висівали на однорядкових ділянках із площею $4,9 \mathrm{~m}^{2}$, із розташуванням рослин $70 \times 70 \mathrm{~cm}$ (2 рослини в гнізді). Стандартами для ліній кукурудзи були селекційні лінії за групами стиглості: ранньостиглі F 2, F 7 (Франція), середньорання УХ 52 (Україна), середньостигла ДС 103 (Україна).

Для місцевих та селекційних сортів стандартами слугували гібриди: Харківський 195 МВ, Харківський 295 MB, Харківський 313 MB. Технологія вирощування колекційних зразків була типовою для зони Лівобережного Лісостепу України.

Погодні умови в роки досліджень (2008-2010) відзначалися значною мінливістю за основними фазами онтогенезу рослин кукурудзи (табл. 1), зі значним дефіцитом опадів.

За роками: 2008 - близький до оптимального, 2009 - спекотний, сухий, 2010 - дуже спекотний, сухий. 
1. Погодні умови в роки проведення дослідів (2008-2010 рр.)

\begin{tabular}{|c|c|c|c|c|c|c|c|c|c|c|c|c|}
\hline \multirow{4}{*}{$\begin{array}{c}\text { Рік } \\
\text { вив- } \\
\text { чен- } \\
\text { ня }\end{array}$} & \multicolumn{12}{|c|}{ Міжфазні періоди } \\
\hline & \multicolumn{4}{|c|}{ сівба - сходи } & \multicolumn{4}{|c|}{$\begin{array}{c}\text { сходи - цвітіння } \\
\text { генеративних органів }\end{array}$} & \multicolumn{4}{|c|}{$\begin{array}{c}\text { цвітіння - воскова } \\
\text { стиглість зерна }\end{array}$} \\
\hline & $\sum$ & $\pm \%$ & $\sum$ & $\pm \%$ & $\sum$ & $\pm \%$ & $\sum$ & $\pm \%$ & $\sum$ & $\pm \%$ & $\sum$ & $\pm \%$ \\
\hline & $\begin{array}{c}\text { актив- } \\
\text { них } \\
\text { t }^{\circ}, \mathrm{C}\end{array}$ & $\begin{array}{c}\text { до } \\
\text { оптим. } \\
\text { умов }\end{array}$ & $\begin{array}{l}\text { опа- } \\
\text { дів, } \\
\text { мм }\end{array}$ & $\begin{array}{c}\text { до } \\
\text { оптим. } \\
\text { умов }\end{array}$ & $\begin{array}{c}\text { актив- } \\
\text { них } \\
\mathrm{t}^{\circ}, \mathrm{C}\end{array}$ & $\begin{array}{c}\text { до } \\
\text { оптим. } \\
\text { умов }\end{array}$ & $\begin{array}{l}\text { опа- } \\
\text { дів, } \\
\text { мм }\end{array}$ & $\begin{array}{c}\text { до } \\
\text { оптим. } \\
\text { умов }\end{array}$ & $\begin{array}{c}\text { актив- } \\
\text { них } \\
\text { t }^{\circ}, \mathrm{C}\end{array}$ & $\begin{array}{c}\text { до } \\
\text { оптим. } \\
\text { умов }\end{array}$ & $\begin{array}{l}\text { опа- } \\
\text { дів, } \\
\text { мм }\end{array}$ & $\begin{array}{c}\text { до } \\
\text { оптим. } \\
\text { умов }\end{array}$ \\
\hline 2008 & 328,4 & $+9,5$ & 65,1 & $-34,9$ & 719,6 & $+2,8$ & 69,2 & $-44,6$ & 1394,2 & $+5,6$ & 123,5 & $+37,2$ \\
\hline 2009 & 336,5 & $+12,2$ & 37,5 & $-62,5$ & 838,9 & $+19,8$ & 31,6 & $-74,7$ & 1359,7 & $+3,0$ & 9,4 & $-89,6$ \\
\hline 2010 & 387,7 & $+29,2$ & 22,1 & $-77,9$ & 843,6 & $+20,5$ & 42,6 & $-65,9$ & 1611,3 & $+22,1$ & 112,2 & $+24,7$ \\
\hline
\end{tabular}

Результати досліджень. У процесі вивчення генетичної різноманітності 110 зразків кукурудзи основна увага в наших дослідах приділялась наступним ознакам: тривалості вегетаційного періоду, продуктивності та іiі складовим, стійкості до враження шкідниками та хворобами, стійкості до вилягання та ламкості стебла, стійкості до впливу стресових кліматичних чинників.

Тривалість вегетаційного періоду - основна ознака, що характеризує екологічний напрям використання вихідного матеріалу в гетерозисній селекції. Вона $\epsilon$ найбільш екологічно мінливою ознакою й обумовлена двома головними чинниками: 3 одного боку, це індивідуальні властивості (генотип) зразка, а з іншого, - умови, в яких він росте і розвивається (температура, вологість, родючість та інше). Розподіляючи зразків по групах стиглості ми враховували такі показники: кількість діб від появи сходів до повної стиглості зерна, кількість листків на рослині з урахуванням суми ефективних температур згідно 3 довідником «Оптимальні умови росту та розвитку рослин кукурудзи», сформованого в Інституті рослинництва ім. В. Я. Юр'єва [6]. Нами підтверджена пряма залежність між кількістю листків на рослині та стиглістю. На основі вивчення даної ознаки більшість зразків відносяться до середньоранніх та середньостиглих. Крім ліній: ОМ 123, Б3 15(ИКВ15) (Росія), 6054-60 (Німеччина), ХЛГ 186, ХЛГ 222, ХЛГ 256 (Україна), сортів: Hanadeka puvod (Україна), Galster (Великобританія), Буштак пешкопійський (Албанія), Скоростигла №8 (Росія), та місцевих сортів з України: UB0103803, UB0103806, UB0103807, UB0103811, які $€$ ранньостиглими. Найпізньостиглішими виявилися зразки: TVA 8030 Op2 (Словаччина), 392 ГМ (Казахстан), НК278 (Україна).
За висотою рослин більшість досліджуваних форм середньорослі та високорослі. Серед самозапилених ліній низькорослими виявилися: ОМ 123 (Росія), ХЛГ 193, ХЛГ 242, ХЛГ 246 (Україна), а серед сортів - Hanadeka puvod, Місцева (UB0103801) (Україна), Місцева Бійська (UB0103818) (Росія). Слід відзначити, що група угорських ліній характеризується високорослістю (160-200 см), високим прикріпленням першого господарськи цінного початка (60-90 см), на головному стеблі 16-18 листків, із середньою по довжині мітелкою (30-40 см) та 15-20 галузками на волоті, середньою та високою зерновою продуктивністю рослин. Якщо в 2008-2009 роках зразки ХЛГ 36, ХЛГ 187, ХЛГ 236, ХЛГ 233, ХЛГ 256, Місцева К 212, Місцева К 206 (Україна) формували по 1,5-1,7 початків, то в 2010 році відмічено на рослині $1,0-1,1$. Потрібно відзначити лінію ХЛГ 248 (Україна), котра стабільно по роках вивчення мала 1,8-2 початка на рослині. Виділено самозапилені лінії кукурудзи, що характеризуються комплексом цінних ознак (оптимальною висотою рослини та висотою прикріплення початка, низьким рівнем вилягання рослин та поникання початків, придатністю до механізованого збирання). Урожайність - основна ознака, що найповніше відтворює біологічні особливості зразка та його реакцію на умови вирощування. Розподіл зразків за зерновою продуктивністю показав, що до досить низькопродуктивних (менше 30 г зерна 3 рослини) відноситься $13 \%$ ліній і $3 \%$ сортів; до низькопродуктивних (30-50 г) - $23 \%$ ліній та $8 \%$ сортів; до середньопродуктивних (50-80 г) - 30\% ліній та $29 \%$ сортів; до високопродуктивних (80100 г) - $13 \%$ ліній та $24 \%$ сортів; до досить високопродуктивних (понад 100 г) - $21 \%$ та $36 \%$ сортів. Високу та стабільну по роках вивчення продуктивність мали зразки, наведені в таблиці 2. 
СІЛЬСЬКЕ ГОСПОДАРСТВО. РОСЛИННИЦТВО

2. Характеристика кращих зразків кукурудзи за господарськи цінними ознаками та елементами продуктивності (2008-2010 рр.)

\begin{tabular}{|c|c|c|c|c|c|c|c|c|c|c|c|}
\hline \multirow{2}{*}{\begin{tabular}{|c|} 
\\
Назва \\
зразка \\
та походження
\end{tabular}} & \multirow{2}{*}{$\begin{array}{c}\text { Проду- } \\
\text { ктив- } \\
\text { ність 1 } \\
\text { росли- } \\
\text { ни, г }\end{array}$} & \multirow[b]{2}{*}{$\begin{array}{l}\text { К-сть днів } \\
\text { від сходів } \\
\text { до повної } \\
\text { стиглості }\end{array}$} & \multicolumn{2}{|c|}{ Висота, см } & \multicolumn{2}{|c|}{$\begin{array}{c}\text { Довжина, } \\
\text { см }\end{array}$} & \multicolumn{3}{|c|}{ Кількість, шт. } & \multirow[b]{2}{*}{$\begin{array}{c}\text { Маса } \\
1000 \\
\text { зерен, } \\
\Gamma\end{array}$} & \multirow{2}{*}{$\begin{array}{c}\text { К-сть } \\
\text { поч- } \\
\text { тків } \\
\text { на } 1 \\
\text { рос- } \\
\text { лині, } \\
\text { шт. }\end{array}$} \\
\hline & & & $\begin{array}{c} \\
\text { росли- } \\
\text { ни }\end{array}$ & $\begin{array}{c}\text { при- } \\
\text { кріп- } \\
\text { лення } \\
\text { почат- } \\
\text { ка }\end{array}$ & $\begin{array}{c}\text { воло- } \\
\text { ті }\end{array}$ & $\begin{array}{c}\text { поча- } \\
\text { тка }\end{array}$ & $\begin{array}{l}\text { рядів } \\
\text { зерен }\end{array}$ & $\begin{array}{c}\text { зерен } \\
\text { в ря- } \\
\text { ду }\end{array}$ & $\begin{array}{l}\text { зерен } \\
\text { на по- } \\
\text { чатку }\end{array}$ & & \\
\hline 1 & 2 & 3 & 4 & 5 & 6 & 7 & 8 & 9 & 10 & 11 & 12 \\
\hline \multicolumn{12}{|c|}{ Сорти і популяції } \\
\hline \begin{tabular}{|c|} 
Місцева НК 278, \\
Україна \\
(UB0110884)
\end{tabular} & 153,6 & 100 & 241 & 72 & 43 & 21 & 11 & 44 & 471 & 318 & 1,1 \\
\hline \begin{tabular}{|l|} 
Doppelhybrig \\
h.k. lool, Австрія \\
(UB0114618) \\
\end{tabular} & 144,8 & 110 & 222 & 75 & 41 & 17 & 15 & 37 & 562 & 289,3 & 1 \\
\hline \begin{tabular}{c|} 
Турчики, \\
Україна \\
\end{tabular} & 144,1 & 100 & 200 & 48 & 37 & 16 & 13 & 31 & 337 & 367 & 1,4 \\
\hline $\begin{array}{l}\text { Місцева, Украї- } \\
\text { на (UB0109711) }\end{array}$ & 141,9 & 114 & 235 & 68 & 41 & 19 & 10 & 38 & 347 & 326 & 1,1 \\
\hline $\begin{array}{l}\text { Місцева, Украї- } \\
\text { на (UB0118729) }\end{array}$ & 137,4 & 120 & 250 & 94 & 37 & 18 & 13 & 36 & 463 & 402,7 & 1 \\
\hline $\begin{array}{l}\text { Місцева, Украї- } \\
\text { на (UB0111492) }\end{array}$ & 129,7 & 106 & 196 & 50 & 39 & 16 & 14 & 30 & 409 & 286,7 & 1,1 \\
\hline $\begin{array}{l}\text { Місцева, Украї- } \\
\text { на (UB0118724) }\end{array}$ & 129 & 110 & 222 & 72 & 38 & 18 & 12 & 41 & 495 & 260,7 & 1,2 \\
\hline $\begin{array}{l}\text { Місцева, Украї- } \\
\text { на (UB0118718), }\end{array}$ & 128,4 & 110 & 254 & 75 & 41 & 19 & 14 & 34 & 462 & 331,4 & 1,0 \\
\hline $\begin{array}{l}\text { Місцева, Украї- } \\
\text { на (UB0118151) }\end{array}$ & 124,4 & 110 & 205 & 55 & 40 & 15 & 13 & 35 & 450 & 302 & 1,2 \\
\hline $\begin{array}{c}\text { Харьківський } \\
295 \mathrm{MB}, \mathrm{cm} .\end{array}$ & 220 & 107 & 232 & 70 & 45 & 21 & 13 & 44 & 561 & 357 & 1,3 \\
\hline $\begin{array}{l}\text { Середнє } \\
\text { по групі }\end{array}$ & 92,5 & 106 & 200 & 58 & 38 & 16 & 13 & 31 & 394 & 285 & 1,1 \\
\hline $\mathrm{HIP}_{0,05}$ & 19,3 & 3,6 & 16,7 & 8,7 & 2,4 & 1,2 & 0,8 & 3,0 & 45,6 & 25,5 & 0,1 \\
\hline \multicolumn{12}{|c|}{ Самозапилені лінії } \\
\hline T 45, Болгарія & 131,2 & 102 & 204 & 64 & 38 & 16 & 15 & 33 & 488 & 315,3 & 1,0 \\
\hline О 5, Угорщина & 124,0 & & 250 & 99 & 44 & 17 & 16 & 39 & 620 & 293 & 1,3 \\
\hline $\begin{array}{c}7-118, \\
\text { Угорщина }\end{array}$ & 117,0 & 118 & 201 & 64 & 40 & 13 & 12 & 29 & 364 & 352,7 & 1,1 \\
\hline $\begin{array}{c}7-120, \\
\text { Угорщина }\end{array}$ & 117,4 & 120 & 203 & 68 & 36 & 16 & 11 & 31 & 353 & 400 & 1,0 \\
\hline $\begin{array}{c}\text { 7-117, } \\
\text { Угорщина } \\
\end{array}$ & 116,6 & 122 & 260 & 91 & 42 & 20 & 14 & 36 & 470 & 424,7 & 1,1 \\
\hline $\begin{array}{c}\text { В 334(ИКВ34), } \\
\text { Росія }\end{array}$ & 115,7 & 107 & 190 & 56 & 34 & 16 & 15 & 31 & 465 & 288,0 & 1,1 \\
\hline ОД 303, Україна & 108,9 & 113 & 172 & 55 & 31 & 12 & 17 & 25 & 425 & 326 & 1,6 \\
\hline ХЛГ 36, Україна & 103,0 & 108 & 170 & 50 & 36 & 15 & 13 & 35 & 433 & 283,3 & 1,1 \\
\hline $\begin{array}{c}\text { ХЛГ 229, } \\
\text { Україна } \\
\end{array}$ & 100,5 & 107 & 190 & 32 & 38 & 16 & 13 & 29 & 357 & 270 & 1,3 \\
\hline
\end{tabular}


СІЛЬСЬКЕ ГОСПОДАРСТВО. РОСЛИННИЦТВО

\begin{tabular}{|c|c|c|c|c|c|c|c|c|c|c|c|}
\hline \multicolumn{12}{|c|}{ Продовження табл. 2} \\
\hline 1 & 2 & 3 & 4 & 5 & 6 & 7 & 8 & 9 & 10 & 11 & 12 \\
\hline $\begin{array}{l}\text { А } 392 \text { ГМ, } \\
\text { Казахстан }\end{array}$ & 98,2 & 122 & 171 & 53 & 35 & 15 & 14 & 30 & 245 & 211 & 1,1 \\
\hline $\begin{array}{c}\text { ХЛГ 248, } \\
\text { Україна }\end{array}$ & 96,2 & 104 & 176 & 40 & 36 & 14 & 13 & 28 & 363 & 279 & 1,8 \\
\hline A $624 \mathrm{MB}$ & 88,1 & 101 & 147 & 38 & 26 & 14 & 14 & 33 & 479 & 217,3 & 1,1 \\
\hline КУ 102, Росія & 85,6 & 113 & 175 & 76 & 30 & 15 & 14 & 31 & 439 & 262 & 1 \\
\hline $\begin{array}{c}\text { ХЛГ 253, } \\
\text { Україна } \\
\end{array}$ & 84,3 & 106 & 145 & 41 & 33 & 14 & 13 & 28 & 352 & 280,7 & 1,1 \\
\hline $\begin{array}{c}7-116, \\
\text { Угорщина }\end{array}$ & 83,8 & 110 & 190 & 52 & 36 & 15 & 11 & 29 & 324 & 262,8 & 1,0 \\
\hline A 513 MB, Росія & 79,1 & 105 & 160 & 56 & 30 & 13 & 16 & 27 & 421 & 240 & 1 \\
\hline $\begin{array}{c}\text { ХЛГ 222, } \\
\text { Україна }\end{array}$ & 77,5 & 98 & 175 & 42 & 35 & 15 & 13 & 31 & 402 & 272,7 & 1,0 \\
\hline $\begin{array}{l}\text { 6054-60, } \\
\text { Німеччина }\end{array}$ & 72,8 & 94 & 167 & 45 & 34 & 14 & 13 & 29 & 359 & 273 & 1,2 \\
\hline$F 2, \mathrm{~cm}$ & 54,9 & 90 & 157 & 43 & 34 & 14 & 11 & 28 & 390 & 264,3 & 1,2 \\
\hline YX 52, cm. & 51,3 & 102 & 149 & 38 & 36 & 12 & 10 & 23 & 238 & 269,0 & 1,2 \\
\hline ДС 103, cm. & 110,2 & 110 & 217 & 79 & 45 & 17 & 12 & 35 & 415 & 252,7 & 1,5 \\
\hline $\begin{array}{l}\text { Середнє } \\
\text { по групі }\end{array}$ & 66,2 & 105 & 158,8 & 45,6 & 32,2 & 13,4 & 12,9 & 25,6 & 340,9 & 251,9 & 1,0 \\
\hline $\mathrm{HIP}_{0,05}$ & 17,3 & 3,9 & 15,1 & 9,2 & 3,2 & 1,3 & 1,1 & 3,5 & 55,6 & 33,7 & 0,1 \\
\hline
\end{tabular}

Небезпечним шкідником молодих рослин кукурудзи $\epsilon$ шведська муха. В середньому за роки вивчення пошкоджуваність рослин цією комахою варіювала в межах 20-60 \% і залежала від погодних умов у період сходів - утворення 4-го, 6-го листків. За ступенем ушкодження рослин кукурудзяним метеликом за роки вивчення лінії розподілилися наступним чином: стійкі (7 \% від загальної кількості) HYWS (Чехія), ХЛГ 217, УХ 1 (Україна); слабо ушкоджені - $60 \%$; середньо сприятливі - $15 \%$; високо сприятливі $18 \%$. Серед сортів стійких виявилося $3 \%$ (Magenta (Велика Британія), Місцева НК67, Місцева (UB0103801) (Україна)), слабо ушкоджених $-37 \%$; середньо сприятливих - $46 \%$; високо сприятливих - $11 \%$. Ушкодження гусінню кукурудзяного метелика 2 покоління в середньому за 3 роки становить 5-20\%. Найстійкішими за роками вивчення до кукурудзяного метелика 1-го та 2-го поколінь виявилися зразки: ХЛГ 193, ХЛГ 222, ХЛГ 246, ХЛГ 193, УХ 1, ДС 303, Місцева НК 238 (Україна), HYWS (Чехія).

Важливим етапом селекції кукурудзи є створення самозапилених ліній та гібридів, які були б стійкими до основних збудників хвороб в Україні [19]. В наших дослідах оцінку стійкості до хвороб проводили на природному фоні. Найбільш шкодочинною хворобою виявився бактеріоз, котрий вражав 40-80\% початків куку- рудзи. Відносно стійкими до бактеріозу (10-20\% пошкодження) були зразки: А 392 ГМ (Казахстан), Турчики та Місцева (UB0103803) 3 України. Ураженість зразків біллю варіювала в межах 20-40 \%. У середньому за роки вивчення стійкими виявились: ОС 20Х, ОМ 60, ОМ 123 (Росія), TVA 8030 Op2 (Словаччина), А 392 ГМ (Казахстан), ХЛГ 222, Турчики, Місцева НК 109, Буштак пешкопійський, Місцева (UB013817) (Україна). Фузаріозом зерно кукурудзи вражалося в середньому на 20-30\%. Стійкими виявилися лінії А 513 МВ, А 624 МВ, М 60, ОМ 123 (Росія), О 14 (Угорщина), TVA 8030 Ор2 (Словаччина), ХЛГ 68, ХЛГ 217, ХЛГ 233, ХЛГ 242 (Україна), а також Місцеві сорти (UB0103809, UB0103769), Місцева К 651 (Україна). Захворюваність початків пліснявою була в межах 5-10\%. За роки вивчення стійкими до цієї хвороби виявилися лінії: ОМ 123 (Росія), 7-117 (Угорщина), ХЛГ 68, ХЛГ 193, ХЛГ 217, ХЛГ 222, ХЛГ 233, ХЛГ 248, ХЛГ 256, ХЛГ 228 (Україна); сорти: Кюма, Місцева (НК 115, К 394), Місцеві форми (UB0103814, UB0103817, UB0103766) (Україна), Скоростигла №8, Скоростигла №33 (Росія), Чинквантино (UB0103872 ), Місцева (К 136, К 101, К 140, К 206, К 446) (Молдова). Високою стійкістю до пухирчатої сажки в природних умовах відзначилися зразки: КИН 090 (Росія), TVA 8030 Op2 (Словаччина), ХЛГ 68, ХЛГ 217, 
СІЛЬСЬКЕ ГОСПОДАРСТВО. РОСЛИННИЦТВО

\section{3. Зразки, виділені за підвищеним вмістом білку (2008-2010 рр.)}

\begin{tabular}{|c|c|c|c|c|c|}
\hline \multirow{2}{*}{$\begin{array}{c}\text { Ноціонального } \\
\text { каталогу }\end{array}$} & Назва зразка & \multirow{2}{*}{$\begin{array}{c}\text { Продуктивність, } \\
\text { г зерна з рослини }\end{array}$} & $\begin{array}{c}\text { Країна } \\
\text { походження }\end{array}$ & білок & крохмаль \\
\hline UВ0100955 & УКХ 325 & 79 & Україна & 13,3 & 68,8 \\
\hline 19131 & А 624МВ & 88,1 & Росія & 12 & 67,9 \\
\hline 18515 & КИН 090 & 49,4 & Росія & 13 & 68,4 \\
\hline 20674 & ХЛГ 36 & 117 & Україна & 13,3 & 67,2 \\
\hline 20635 & УХ 1 & 34,8 & Україна & 12,4 & 63,3 \\
\hline 4764 & $\begin{array}{c}\text { Молдаванка } \\
\text { краснуха }\end{array}$ & 66,6 & Україна & 12,3 & 67,4 \\
\hline 12039 & Місцева жовта & 79,7 & Україна & 12 & 69,5 \\
\hline 11832 & Місцева & 37,2 & Україна & 12,7 & 67,9 \\
\hline 12330 & Місцева Бійская & 38,7 & Росія & 12,1 & 69,3 \\
\hline 00274 & Zоnglellov & 102,1 & США & 12,3 & 71,2 \\
\hline
\end{tabular}

ХЛГ 233, ХЛГ 242, ХЛГ 256, Місцева (UB0103772) (Україна). Відносну стійкість до комплексу захворювань кукурудзи (70-80 \% здорових початків) мали: ОМ 123 (Росія), TVA 8030 Op2 (Словаччина), ХЛГ 68, ХЛГ 246, Місцева (UB0103803, UB0103810) (Україна).

У 2008-2009 роках досліджувався вміст білку та крохмалю в зерні даного набору зразків. Із-поміж сортів $17 \%$ зразків віднесено до групи 3 низьким вмістом білку (8-9 \%), 76 \% - до групи з середнім вмістом білку (9-12\%). До групи 3 підвищеним вмістом білку $(12,1-16,0 \%)$ та стабільним проявом цієї ознаки відносилися $7 \%$ сортів: Місцева (К 446, К 630), Місцева (UB0103864) (Молдова), Місцева (UB0103816, UB0103807) (Україна), Місцева Бійська (Росія), Zonglellow (США). У 9 \% ліній вміст білку був низький, а решта ліній мала середній вміст білку. Більшість зразків мали 60-70 \% крохмалю. Серед ліній 71-72 \% крохмалю мали: 7-120 (Угорщина), ОС 20Х (Росія), ХЛГ 52, ХЛГ 222, ХЛГ 245, ХЛГ 256 (Україна), а також місцеві сорти українського походження: UB0103811, UB0103810, UB0103805, UB0103765.

Висновки: 1. У результаті проведеної роботи 3 колекційними зразками кукурудзи виділено сорти та самозапилені лінії кукурудзи зі стабільно високою зерновою продуктивністю та ії складовими (кількість зерен на початку, кількість

\section{БІБЛІОГРАФІЯ}

1. Антонюк С. П., Вишневський М. В., Гаркава О. М. Добір вихідного матеріалу кукурудзи на жаростійкість //Сучасні технології селекційного процесу сільськогосподарських культур: Тези наук. Міжнарод. сімпозіуму. - Х., 2004. - С. 69.

2. Гурьев Б. П. Основные результаты и некото- рядів зерен на початку, довжина початка, маса 1000 зерен).

2. Проведено розподіл зразків по групах стиглості.

3. Виділено зразки з підвищеним вмістом білку та крохмалю в зерні кукурудзи.

4. На природному фоні виділено зразки стійкі до шкідників та хвороб, що пропонуються для використання в селекції гібридів кукурудзи. За результатами вивчення у Національному центрі генетичних ресурсів рослин України зареєстровано цінні зразки кукурудзи: UB0103818 Местная Бийская (Росія) - джерело ранньостиглості (88 діб), високого вмісту білку $(12,2 \%)$, запит № 913 від 29.09.2012, та UB0103755 T 45 (Болгарія) - джерело продуктивності (130 г зерна з рослини), маси 1000 зерен (315 г), високобілковості $(12,4 \%), \quad$ високої стійкості до ураження пухирчастою сажкою (9 балів) та ушкодження кукурудзяним метеликом (7 балів), запит № 914 від 29.09.2012. Також передано на реєстрацію 7 зразків: UB0103753 TVA 8030 Op2 (Словаччина), UB0103814 Micцева форма (Україна), UB0103864 Місцева форма (Молдова), UB0103867 Місцева форма К101 (Молдова), UB0103854 А 392 ГМ (Казахстан), UB0103741 A 624 MB (Росія), UB0103748 ОM 123 (Росія).

рые вопросы селекции раннеспелых гибридов кукурузы // Селекция и семеноводство. - К. : Урожай, 1972. - Вып. 20. - С. 22-31.

3. Гурьев Б. П., Черномыз А. Н. Селекция самоопыленных линий с повышенной семенной продуктивностью // Кукуруза. - 1976. - №5. - С. 26. 
4. Гурьев Б. П. Селекция кукурузы на раннеспелость / Б. П. Гурьев, И. А. Гурьева. - М. : ВО Агропромиздат, 1990. - $173 \mathrm{c}$.

5. Гур'єва I. А., Вакуленко С. М., Степанова В. П., Кузьмишина Н. В. Генетичний потенціал сучасного вихідного матеріалу кукурудзи // Генетика i селекція на межі тисячоліть. - К. : Логос, 2001. T. 2. - C. 610-615.

6. Гур'єва I. А., Кузьмишина Н. В. Цінний вихідний матеріал для селекції самозапилених ліній кукурудзи // Фактори експериментальної еволюції організмів. - К., 2004. - С. 341-344.

7. Гурєва I. А., Рябчун В. К. Генетичні ресурси кукурудзи в Україні. - Х., 2007. - 391 с.

8. Зозуля А. Л. Способность определения потенциальной продуктивности самоопыленных линий // Селекция и семеноводство. - Вып. 40. К., 1978. - C. 31-34.

9. Козубенко В. Е. Селекция кукурузы. - М. : Колос, 1965. - $206 \mathrm{c}$.

10. Кононенко O. В. Взаємозв'язок продуктивності $з$ елементами структури качана у ліній кукурудзи // Наукові проблеми виробництва зерна в Україні та сучасні методи їх вирішення: Тези Всеукр. наук.-практ. конфер. молод. вчених i спеціал. - Дніпропетровськ, 2000. - С. 74.

11. Класифікатор-довідник виду Zea mays L. - X. : IP, 1994. - $72 \mathrm{c}$.

12. Козубенко Л. В. Селекция кукурузы на раннеспелость / Козубенко Л. В., Гурьева И. А. - Х.,
2000. -239 c.

13. Методичні рекомендації польового та лабораторного вивчення генетичних ресурсів кукурудзи / I. А. Гур'єва, В. К. Рябчун, П. П. Літун [та ін.] - Х., 2003. -43 с.

14. Мустяиа С. И., Борозан П. П., Мистрец С. И. Итоги селекционной работы с раннеспелой кремнистой зародышевой плазмой // Кукуруза и сорго. - 2001. - №6. - С. 10-16.

15. Филлипов Г. Л. О критериях оценки скороспелости гибридов кукурузы для агроклиматического обоснования их районирования / Филлипов Г. Л., Домашнев П. О. // Бюл. ВНИИ кукурузы. - 1982. - №60. - С. 3-8.

16. Чупіков М. М. Цінний вихідний матеріал для створення селекції гібридів кукурудзи / Чупіков М. М., Овсяннікова Н. С., Барсуков І. П. // Генетичні ресурси рослин : науковий журнал. №4. - Х., 2007. - C. 64-69.

17. Шмараєв Г. Е. Биологическая и селекционная ценность раннеспелой кукурузы из Испании и Португалии / Г. Е. Шмараев, А. Д. Барсуков // Тр. по прикладной ботанике и селекции. - Л., 1984. - Т. 84. - C. 112-118.

18. Шмараєв $Г$. Е. Исходный материал кукурузы для селекции высокопродуктивных гибридов зернового и силосного использования / Г. Е. Шмараев, В. С. Мельник // Науч.-технич. бюл. - Л., 1985. №156. - C. 112-118. 